\title{
Open Networks, Open Books: Gender, Precarity and Solidarity in Digital Publishing
}

\author{
by Christine Larson
}

\author{
University of Colorado, Boulder
}

\begin{abstract}
The nature of work is changing, from secure, full-time jobs to a 'risk regime' characterized by alternative work arrangements and a pervasive sense of insecurity [Beck, U. (2000). The brave new world of work. Polity: Malden, MA]. While these conditions resemble those long endured by cultural workers, scholarly exploration of these similarities has stalled: Digital optimists extoll the value of self-enterprise, while critical cultural scholars decry such claims as a smokescreen for deteriorating labor conditions, which inevitably promote insecurity (or 'precarity'). This paper attempts to end the stalemate by proposing three measures of insecurity and applying them to a group of cultural workers-romance authors. Through a survey of 4270 romance authors, I show their median income nearly doubled after the rise of digital self-publishing, while other authors' incomes dropped. Interviews with 78 authors and editors suggest this resilience relates to professional tactics developed in the 1980s amidst pervasive gender bias. Specifically, romance authors developed an 'open-elite' network, an arrangement

historically associated with innovation, which was later amplified by interactive communication technologies [Powell, W. W., \& Owen-Smith, J. (2012). An open elite: Arbiters, catalysts, or gatekeepers in the dynamics of industry evolution. In The emergence of organizations and markets (pp. 466-495). Princeton, NJ: Princeton University Press]. This research contributes to debates around self-employment, cultural work and precarity. It shows increased insecurity is not inevitable in the risk regime, but

rather that specific professional practices, enhanced by ICTs, can increase workers' resilience.].
\end{abstract}

\section{Introduction}

The nature of work is changing. For most of the twentieth century, a decent job meant a secure, long-term position. In recent decades, however, more workers have come to depend on part-time work, temporary gigs, second jobs and consulting projects, constitut-ing 'portfolio careers' (Handy, 1991). Labor economists Katz and Krueger tracked a small but steady rise in 'alternative work' between 2005 and 2015 (Katz \& Krueger, 2019), and Lowe found that traditional markers of steady employment (such as government work) were now, surprisingly, associated with increased perception of job insecurity (Lowe, 
2018). Such developments characterize what Beck called the 'risk regime ... a political economy of insecurity, uncertainty and loss of boundaries' (Beck, 2000, p. 73). A growing literature associates this regime with 'precarity,' defined as work with unpredictable pay, little access to health benefits, individualized working conditions and scant guarantee of continued employment (de Peuter, 2011).

As more people experience insecure conditions, the figures of the artist, writer and musician have become emblematic of the future of work (Florida, 2002; Pink, 2002). Such creators have long lived within a risk regime, performing sporadic, unpredictable gigs for uncertain returns. Paradoxically, however, these creative cultural workers, whom Banks defines as 'responsible for the productions of symbolic commodities' or 'texts' such as books, music and movies (Banks, 2007, p. 7), have come to signify two opposing sides in a deadlocked debate over labor in the digital economy.

On one hand, for digital optimists like Richard Florida and Daniel Pink, creative cultural workers represent the ideal post-industrial entrepreneur, enjoying autonomy through self-enterprise, while driving economic growth (Florida, 2002; Terranova, 2000; Pink, 2002). On the other, for critical cultural scholars, cultural workers signify something much darker - the growing precarity of labor (Banks, 2007, p. 29; Duffy, 2017; McRobbie, 2015, p. 42). This camp argues that digital technologies, combined with trends toward globalization and deregulation, have allowed firms to shift the costs and risks of employment to workers, replacing secure positions with precarious jobs defined by inevitable 'financial, social and existential insecurity' (de Peuter, 2014, p. 266). These scholars, and the precarity literature in general, tend to view the rhetoric of digital entrepreneurism as a smokescreen obscuring oppressive and unfair labor con-ditions, which especially disempower workers outside the white male paradigm (Duffy \& Pruchniewska, 2017).

The stalemate between these two camps occurs at an unfortunate moment, given growing awareness of the contemporary risk regime. To deny the dark side of insecure employment seems disingenuous and short-sighted (Banks, 2007; Duffy, 2016; Gill \& Pratt, 2008; Ross, 2009); to dismiss the potential opportunities of self-entrepreneurism, however, pre-cludes the potential of resistance and resilience in the face of new economic structures (de Peuter, 2014). The more the structure of employment in general comes to resemble cul-tural industries' working patterns, the more critical it becomes to resolve this deadlock and arrive at a more nuanced understanding of these fields and the lessons they offer for independent digital workers. As Banks put it, it is now 'an empirical necessity that we learn more about the working lives of creative cultural workers' (Banks, 2007, p. 8).

To do so, three specific shortcomings in the discussion must be addressed. First, arguments about the relative insecurity of creative workers generally lack quantitative evidence. Such data would augment many outstanding ethnographic studies of cultural industries (Duffy, 2013, 2016; Hesmondhalgh \& Baker, 2011; McRobbie, 2013, 2015; Neff, 2012; Neff, Wissinger, \& Zukin, 2005).

Second, both sides tend to overgeneralize about the nature of cultural labor, failing to discriminate between specific industries (Banks, 2007, p. 27; Gill \& Pratt, 2008, p. 13; McRobbie, 2015, p. 106). This limits the ability of scholars to identify specific practices that may improve working conditions for some groups.

Finally, both sides often overlook gender differences in labor (Gill, 2006; McRobbie, 2015, p. 93) As Fantone notes, much of the precarity literature presumes a male worker 
and ignores the fact that insecure, poorly paid labor has long been the norm for women (Fantone 2007, quoted in Gill, 2006, p. 1). The underlying paradigm of the full-time white male worker has too often led critical theorists to equate workforce reform primarily with (male-oriented) labor unions, rendering invisible alternative forms of resistance and resilience (Banks, 2007, p. 5; Gill \& Pratt, 2008, p. 19; McRobbie, 2013; Coker 2015, p. 102).

Book publishing offers a rich opportunity to develop a more nuanced understanding of insecurity and resilience. Authors have long been insecure workers, living project to project, holding day jobs, lacking health insurance or long-term security and subject to the whim of publishers. Since the introduction of the Kindle in 2007, authors' security seems to have deteriorated: the book-related median income of US authors plummeted 42\% between 2009 and 2014 (The Authors' Guild, 2015).

However, one group of authors - romance writers - has shown astonishing resilience. The genre's popularity rose so dramatically after the introduction of e-books that The Guardian credited romance writers with driving the adoption of e-readers, and The New York Times christened them publishing's 'most innovative participants' (Flood, 2016; Holson, 2016). Moreover, the romance genre has a long history of quickly absorbing innovations: Radway's groundbreaking 1984 study of romance readers notes that the 1970s romance boom resulted from the rapid adoption of new binding techniques and distribution tactics (Radway, 1991, pp. 35-44). Radway observes that, even then, distinctive practices, including usually close relationships with fans, set romance writers apart from other authors (Radway, 1991, pp. 68, 95). Thus, romance offers an opportunity to examine a sector of insecure workers who have consistently shown resilience in the face of change.

This paper draws on a survey of 4270 romance writers, and interviews with 78 authors and editors, to explicate insecurity and resilience under digital conditions. I find that after the rise of e-books, romance writers became more economically secure; their median income rose $73 \%$. At the same time, they increased their job security by adding a new income stream - selling directly to readers, not to publishers - which reduced their absolute dependence on traditional publishers. In this way, they exploited the tendency of 'platformized' industries (those whose fundamental operations have been reshaped by the 'economic, governmental and infrastructural extensions of digital platforms') to develop multi-sided markets (Nieborg \& Poell, 2018, p. 4276).

I explain the group's resilience by identifying specific network and professional tactics that rose in the 1980s, and which many romance authors perceived as defenses against industry-wide gender bias. In the 2000s, the rise of interactive communication technologies augmented these pre-existing strategies. Specifically, over four decades, these authors developed an 'open-elite' network, a type of network associated with innovation at critical times across history (Padgett, 2010; Powell \& Owen-Smith, 2012; Stone \& Stone, 1986). This network, with its ready opportunities for rapid transfer of new knowledge during a period of disruption, helped position romance writers for rapid success.

This paper proceeds in three sections. Section I explains how scholars have approached book publishing, precarity and cultural industries. Section II presents findings from my survey of romance writers $(n=4270)$ and compares them to a similar study of a broader group of nonfiction, literary and genre fiction authors. Section III draws on participantobservation, archival research and interviews with 78 writers and industry experts to explicate professional practices associated with romance writers' resiliency in the face of digital disruption. 
Ultimately, the data presented here challenge a key assumption of cultural industries scholars that digital conditions necessarily render cultural workers more precarious. However, this research does not wholeheartedly support digital optimists. Rather, it shows that certain social tactics have the potential, though not the certainty, to improve working life even under insecure conditions.

\section{Book publishing as a cultural industry}

Book publishing offers a case study of a centuries-old industry transformed by ICTs. It neatly exemplifies key features of other cultural industries, including, (1) a high level of risk; (2) a tension between creativity and commerce (Coser, 1979; Thompson, 2012); and, (3) high 'first copy' costs, but low reproduction costs (Hamilton, 2004; Hesmondhalgh, 2007).

Like other cultural firms, publishers cope with these challenges by building product portfolios where hits compensate for misses; by 'formatting' (using well-known genres or authors to signal a book's qualities (Hamilton, 2004; Ryan, 1992); and by loosely controlling creators, but tightly managing distribution and marketing (Hesmondhalgh, 2007). Like other cultural industries, books have experienced a rapid rise in do-it-yourself production and circulation, thanks to ICTs which have lowered production, distribution and marketing costs (Lobato \& Thomas, 2015). And, like other cultural industries, the new logics of web-based production and distribution have reshaped the way authors develop and market their cultural products (Nieborg \& Poell, 2018).

Oddly, however, cultural production scholars have rarely studied the labor of authors, instead focusing on 'hot jobs' in fields like music, TV and film, fashion, blogging or dotcom work (Baym, 2018; Duffy, 2016; Hesmondhalgh \& Baker, 2008; McRobbie, 2013, 2015; Neff, 2012; Neff et al., 2005; Ross, 2004). Radway's classic Reading the Romance provides invaluable insight into the business of romance, but focuses primarily on readers, not writers (Radway, 1991). More recently, Striphas' The Late Age of Print analyzes the contemporary book ecosystem, but emphasizes 'book culture,' not labor (Striphas, 2009).

Bridges' outstanding study of book editors illuminates the gendered inequalities of flexible labor, but does not address authors (Bridges, 2018). And while media economists (Elberse, 2013; Greco, 1997; Waldfogel \& Reimers, 2015; Whiteside, 1981) and organizational theorists (Coser, Kadushin, \& Powell, 1982; Powell, 1985; Thompson, 2012; Thornton, 2004) have dissected the inner workings of the book industry, these writers, too, typically gloss over authors' labor.

Yet authors have long occupied the position that many workers find themselves in today: self-enterprising producers, dependent on powerful intermediaries (in authors' cases, traditional publishers) to finance their projects, market their services, find customers and, generally, broker their piecemeal labor in return for an unpredictable payout. These conditions resemble those of many precarious workers, from Uber drivers to social media consultants to high tech contractors (Barley \& Kunda, 2006; de Peuter, 2011; Malin \& Chandler, 2016; Scolere, Pruchniewska, \& Duffy, 2018). All these workers - including authors - exemplify key facets of precarity (de Peuter, 2014; Gill \& Pratt, 2008): often, though not always, poorly paid, they have little access to health benefits. Even if well paid, they cannot predict how much they might earn from one month to the next. They are 'fractalized' and 'mobile,' working independently, typically with little peer 
contact (de Peuter, 2011). They work flexible hours, but since their income depends on their hours, they feel constant pressure to work more. Unlike many newly precarious workers, however, authors have a long history coping with such conditions; thus, they may have lessons to teach workers in the risk regime.

Within book publishing, romance writers offer a compelling case because of their disproportionate success. Once a highly stigmatized genre, romance novels are now recognized as a significant cultural force (Gill, 2006; Gill \& Herdieckerhoff, 2006). Since the 1980 s, romance has been one of the most economically powerful sectors of the book industry. In 2015 romance generated 25\% (\$72 million) of the \$286 million adult fiction market, far more than any other genre (Meyer \& McLean, 2016). In addition, romance has led the way in digital publishing. From the launch of the Kindle in 2007 and the iPad in 2010, romance e-books have significantly outsold other genres (Coker, 2015; Meyer \& McLean, 2016).

One popular, but specious, explanation for this disproportionate success suggests that because e-books do not display book covers, they tap new readers previously put off by racy romance covers. While this explanation evokes the well-documented shaming of romance readers (Lois \& Gregson, 2015), it relies on faulty assumptions and outdated clichés about contemporary romance covers, which today are far less likely to feature Fabio look-alikes in the clinch with buxom beauties. The cover of Fifty Shades of Grey, for instance, simply shows a silver tie on a black background. Another explanation argues that e-books allow voracious romance readers to download a new read immediately after finishing a book (romance readers read more than four times as many books annually as the average American (Meyer \& McLean, 2016; Perrin, 2018)); however, this only brings us back to the same questions - how do they generate such enormous demand? What do romance writers know that other authors don't?

Finally, romance writers offer an excellent opportunity for addressing gender omissions in cultural industries studies because romances are overwhelmingly written by women. A study of romance writers necessarily centers female workers and challenges androcentric definitions of work or solidarity. In centering gender in creative labor discourse, I follow recent scholarship including Duffy's study of social media workers (Duffy, 2017), McRobbie's work on the Berlin fashion industry (McRobbie, 2015) and Bridges' work on editors (Bridges, 2018).

In summary, the high-profile success of romance in the age of e-books raises questions central to debates around ICTs, self-enterprise and cultural industries. Why did digital disruption improve working conditions for romance writers, but not other authors? How can we measure changes in security? And how can we identify factors that may improve working life under digital conditions?

\section{Research questions and methods}

To explore these issues, we must address two questions:

(1) Are these writers more or less precarious than before the digital disruptions of e-books and self-publishing? 
(2) If less so, why? What professional practices, relationships or market changes might account for an overall improvement at a time when other writers and content creators became more precarious?

To answer these questions, I developed three measures of precarity. Next, I administered an income and professional practices survey to members of Romance Writers of America, a 10,000-member association founded in 1980. Separate from the survey, I also conducted semi-structured interviews with 58 writers and 20 publishing professionals and completed 84 hours of participant-observation at romance writer and fan events. My interviews began with a purposive sample of 20 key informants (Tremblay, 1955), selected by combing self-published best-seller lists and by asking industry insiders for key informants. Through snowball sampling, this initial set led to an additional 58 interviews with authors, editors and publishers (Biernacki \& Waldorf, 1981).

\section{Measures of precarity}

If romance writers became less precarious after the rise of digital publishing, we would expect to see the following tendencies:

1. A rise in median income. Income in entertainment industries is highly skewed; most creators earn very little, while a few earn mindboggling sums (Rosen, 1981; Terviö, 2009). Thus, median, rather than mean, income offers the most appropriate measure.

2. More writers earning more than the US median, and more than $\$ 100,000$. To indicate how many authors make a living from their writing, this paper measures the percentage of authors surpassing two indicators of economic security: the U.S. median income, and $\$ 100,000$ a year, often considered a benchmark of financial success (JamesEnger, 2013)

3. Fewer writers holding 'day jobs.' Authors were defined as having 'no day job' (a classic measure of creative success) for a given year if they reported romance novels as their only source of income.

Survey design. To assess romance writers' relative precarity before and after the rise of ereaders, the survey asked 49 questions about professional practices and income for 2009 and 2014. Authors were asked to recall all book-related gross earnings from romance, including self-publishing and traditional publishing. Additional questions asked about attitudes toward the industry, how frequently respondents network with other writers; their use of ICTs; and their most common sources of professional advice.

Survey distribution and response. To limit respondents to professional authors, the survey targeted members of Romance Writers of America (RWA), a professional association open to authors 'seriously pursuing a romance fiction writing career' aiming to earn a full-time, or 'generous' part-time, income from writing. RWA's entire membership $(n=10,240)$ received e-mail invitations to participate in an online survey. Participants were entered in a drawing for five \$20 Amazon gift cards, and one entry to the 2016 RWA convention. 4270 (41.7\%) responded, though not all responded to every question. 
Representativeness. RWA does not represent all romance writers: Analyzing four randomly-selected bestseller lists from USA Today in 2015 showed that only $44 \%$ of bestselling romance authors listed belonged to RWA. In addition, those responding to the survey were more likely to belong to RWA's internal networks for published authors; likewise, a smaller subsample of respondents who reported two years of income had written more manuscripts and pursued publication longer than other respondents. Thus, results cannot be generalized to the entire romance genre, but rather to those romance writers who join professional networks and have some degree of success (see Tables 1 and 2).

In recognition of this limitation, this survey was supplemented by qualitative interviews with 41 romance authors (30 participated in and were drawn from the survey; 11 were selected off self-published or traditional bestseller lists) and 37 editors and other publishing professionals. While this does not increase the representativeness of the survey, it does help include perspectives from outside the sample.

To develop a sample for income analysis, filters screened for authors who reported nonzero income for 2009, and any income - including zero income - for $2014(n=668)$. Excluding zero income earlier for $2009(n=186)$ ensured a population that was actively publishing before 2010, when e-books and digital self-publishing grew sharply; including zero income earners for $2014(n=23)$, allows us to follow this entire population, even if they cease to earn income. Respondents who reported zero income for both 2009 and 2014 were excluded $(n=63)$, on the assumption that they were not active during this period.

Survival bias. Discouraged authors may have failed to enter data for 2014, declined to complete the survey, or dropped out of RWA altogether. Thus, the sample may be biased toward more successful or optimistic authors. To help allay this concern, I obtained comparable income figures from a survey by the Authors' Guild (2015).

The Authors' Guild survey was conducted in 2015 by research firm Codex and administered to all Authors' Guild members; as in the romance survey, members were invited by email to take an online survey; respondents were entered in a drawing for $\$ 25$ gift cards. As in the romance survey, respondents were asked to recall and report their book-related income for 2009 and 2014. In both surveys, 'book-related' income included advances, royalties, subsidiary, film, audio and international rights and book prizes or awards (HildickSmith, 2016).

Table 1. Comparison of RWA survey response to RWA population.

\begin{tabular}{lcc}
\hline & $\begin{array}{c}\text { RWA member population } \\
\text { (total population) } n=10,24 \text { (RWA }\end{array}$ & \multicolumn{1}{c}{$\begin{array}{c}\text { Survey } \\
\text { respondents }\end{array}$} \\
Mean length of RWA membership & $2017)$ & 8 years (SD 8) $n=4110$ \\
$\quad$ Members of PAN (Published Authors' Network, an RWA & 9 years & $42 \% n=4150$ \\
$\quad$ network for published authors) & $30 \%$ & $27 \% n=4150$ \\
Members of PRO (a network for unpublished members & & \\
$\quad$ who have completed one or more manuscripts) & $21 \%$ & $n=4116$ \\
State of residence & & $13 \%$ \\
California & $11 \%$ & $9 \%$ \\
Texas & $9 \%$ & $5 \%$ \\
New York & $7 \%$ & $7 \%$ \\
Florida & $6 \%$ &
\end{tabular}


Table 2. Comparison of income subsample to all respondents.

Analysis set

Mean length RWA membership (SD)

Mean years pursuing publication (SD)

Mean number of manuscripts completed (SD)

Median income from romance writing 2014 (IQR)

\author{
15 years (8) $n=649^{\text {a }}$ \\ 18 (9) $n=637^{\mathrm{a}}$ \\ $15(8) n=649^{\mathrm{a}}$ \\ $\$ 10,100(\$ 1200, \$ 52,812) n=668$
}

All survey respondents

8 years (8) $n=4110$

10 (8) $n=4084$

$11(17) n=4014$

$\$ 3500$ (IQR: $\$ 300, \$ 25,000)$ $n=1977$

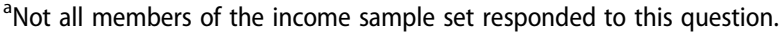

The Codex survey included 111 questions, on income, marketing, and Authors' Guild programming. $74 \%$ of those who began the survey completed it, yielding a sample of 1,674 respondents. On average, Authors' Guild respondents were older and more educated than RWA respondents and were more likely to be male (see Table 3). At my request, Codex applied the same filters used for the romance survey, looking at book-related income for authors who earned nonzero income in 2009 and reported either zero or nonzero income for 2014; the income analysis set included 1,095 writers.

Given the similar methodology and analysis, it seems plausible to assume survival bias is constant between groups and that resulting income trends are meaningful.

Analysis. All 2009 figures were adjusted to 2014 dollars. Tests of significance comparing median income used the Wilcoxan signed rank test for paired nonparametric data. Tests of significance comparing increase in percentage of authors earning benchmark amounts or holding day jobs used two-sample tests of proportion.

\section{Section II: Romance writers became less precarious on all measures}

All measures showed a decrease in insecurity after the rise of digital self- publishing.

\section{Measure 1: Median income rose for all writers. Hybrids did best.}

Median income from romance writing grew 73\%, from $\$ 5828$ (IQR $\$ 1135, \$ 33,358$ ) to $\$ 10,100$ (IQR $\$ 1200, \$ 52,812)(p<.001)$ (Table 4). In startling contrast, the Authors' Guild survey, described above, showed an income decline of $42 \%$ during the same period, from $\$ 6924$ in 2009 to $\$ 3750$ in 2014 (Hildick-Smith, 2016). Thus, at a time when most authors became more economically precarious, romance authors became more secure.

To be sure, romance writers' median incomes were far lower than the US median income ( $\$ 39,000$ for women in 2014). But this is exactly the point. Authors and other cultural laborers have come to represent insecure workers precisely because most have never earned sustainable incomes from their cultural work. Rather, like a growing number of contemporary workers, they have long relied on multiple gigs and income streams to make ends meet.

Table 3. RWA vs. Authors' guild respondents.

\begin{tabular}{lll}
\hline & \multicolumn{1}{c}{ RWA } & \multicolumn{1}{c}{ Authors' Guild } \\
\hline Age & $50 \%$ older than 50 & $89 \%$ older than 50 \\
Gender & $98 \%$ women & $62 \%$ women \\
Graduate degree & $61 \%$ & $36 \%$ \\
\hline
\end{tabular}


Table 4. Change in median income for romance authors vs Authors' Guild, 2009-2014.

\begin{tabular}{lllll}
\hline$N=668^{\text {a }}$ & \multicolumn{1}{c}{2009 median $^{* *}$} & \multicolumn{1}{c}{2014 median } & $p$ value** & Percent change \\
\hline Median income (IQR) & $\$ 5828(\$ 1135, \$ 33,358)$ & $\$ 10,100(\$ 1200, \$ 52,812)$ & $<0.001$ & $+73 \%$ \\
Authors' Guild $(n=1095)$ & $\$ 6924$ & $\$ 3,750^{* * * *}$ & $* * *$ & $-42 \%$ \\
\hline
\end{tabular}

${ }^{a}$ This figure excludes authors who reported zero book-related income in $2009(n=183)$, but includes zero-income earners for $2014(n=23) .63$ authors reporting zero income for both years were also excluded.

**2009 figures are adjusted to 2014 dollars.

***Wilcoxon signed rank test for paired nonparametric data.

****Author's Guild (2015) did not furnish original data set, so variability and significance figures were not available.

It is important to note that not all types of romance authors saw income growth; in fact, all growth came from 'hybrid' authors - those who published both through traditional publishers and through their own self-publishing efforts (Table 5). Those authors who were self-publishing and did not move to traditional publishing, or vice versa, saw no growth in income - although, unlike respondents in the Authors' Guild survey, their income did hold steady.

Among hybrid authors, the vast majority (96\%) started out as traditionally published authors, then added self-publishing; only $4 \%$ of hybrid authors began by self-publishing and were later signed by traditional publishers (Table 6). This suggests that, at least during the early years of self-publishing, platformization mostly benefited traditionally published authors, who, by adding self-publishing, were able to profit both from the one-sided market of traditional publishing (where authors sell rights to publishers) and from a new market - readers themselves, who could now purchase books directly from the author. Thus, hybrid authors could now reach two types of customers where only one had existed before. As noted earlier, this development exemplifies the tendency of platformization to generate multi-sided markets (Nieborg \& Poell, 2018).

Table 5. Change in median income by publication category ${ }^{\mathrm{a}}, 2009-2014$.

\begin{tabular}{llll}
\hline$N=662^{\text {b }}$ & \multicolumn{1}{c}{ 2009 median } & \multicolumn{1}{c}{2014 median } & $p$ value \\
\hline Traditionally published only $n=314$ & $\$ 4540($ IQR \$795, \$28,275) & \$5000 (IQR \$500, \$35,000) & $=0.30$ \\
$\begin{array}{l}\text { Hybrid (both traditionally and self-published } \\
\text { in either or both 2009 or 2014) } n=336\end{array}$ & $\$ 9080$ (IQR \$1362, \$34,050) & $\$ 20,400($ IQR \$2900, \$76,500) & $<0.001$ \\
Self-published only, 2009 and 2014 $n=12$ & $\$ 851$ (IQR \$170, \$4256) & $\$ 1500($ IQR \$350, \$4200) & $=0.75$ \\
\hline
\end{tabular}

${ }^{a}$ Traditionally and self-published authors were defined as authors who published solely in one category in both years. 'Hybrid authors' reported income from both categories in one or both years, or from traditional publishing in one year and self-publishing in the other.

'Six respondents were excluded from this analysis because, for at least one year, they reported income only from 'other' sources of romance writing (short stories, ancillary rights, etc.) and did not fall into one of these three categories.

***Wilcoxon signed rank test for paired nonparametric data.

Table 6. Percentage of hybrid authors first published traditionally vs. self-published.

\begin{tabular}{lcccc}
\hline & $\begin{array}{c}\text { Percent of } \\
\text { hybrids }\end{array}$ & \multicolumn{1}{c}{2009} & 2014 & $p$ value $^{*}$ \\
\hline $\begin{array}{c}\text { Traditionally published } \\
\text { first }(n=324)\end{array}$ & $96 \%$ & $\$ 11,350($ IQR \$1516, \$34,617) & \$20,750 (IQR \$2950, \$74,012) & $<0.001$ \\
$\begin{array}{l}\text { Self-published first }(n=12) \\
\text { S }\end{array}$ & $4 \%$ & $\$ 3246($ IQR \$199, \$6810) & $\$ 9500(\$ 1588, \$ 415,000)$ & $p<0.001$ \\
\hline
\end{tabular}

*Wilcoxon signed rank test for paired nonparametric data. 
Traditional authors who added self-publishing tended to have different types of connections within the romance network than traditional authors who did not. Elsewhere, I have shown that traditional authors who became hybrids tended to seek advice from industry newcomers more often than did traditional authors who did not become hybrids (Larson, 2017).

These observations raise further questions about the interaction of concentrated legacy media firms and dispersed, independent media producers (Jenkins, 2004). Although beyond the scope of this paper, such questions suggest fertile directions for future work.

In any case, the data presented here point to the effectiveness of romance writers' tactics in exploiting new ICTS to reduce precarity (specifically, dependence on old media firms) and develop resilience.

\section{Measure 2: Romance writers became more likely to exceed US median income and $\$ 100,000$}

Between 2009 and 2014, a greater percentage of writers exceeded two key benchmarks (Table 7).

The 'Virginia Woolf Index. In 1928, Virginia Woolf wrote that a woman author needs a room of her own and '500 pounds a year' - a modest but stable income (500 pounds in 1928 equals about $\$ 34,000$ in 2016). Today, the US median income provides a strikingly similar measure of modest security (the US median for women was $\$ 35,549$ in 2009 and $\$ 39,621$ in 2014, according to the US Bureau of Labor Statistics; because 98\% of survey respondents were women, the US median for women is a more appropriate benchmark than overall median). From 2009 to 2014, the percentage of women romance writers exceeding this benchmark increased from $22 \%$ in 2009 to $31 \%$ in $2014(n=659)(p<.001)$ (Table 6).

$\$ 100,000$ a year. The percentage of respondents earning more than $\$ 100,000$ a year nearly doubled, from $9 \%$ to $17 \%(p<.001)$.

\section{Measure 3: More romance writers quit their day job}

Between 2009 and 2014, the percentage of romance writers reporting 'no other source of income' rose from 39 to $45 \%(n=660)(p<.05)$ (Table 5). During the same period, Authors' Guild members saw no change in percentage of day-job holders (39\% for both years) $(n=1095)$. (Table 7$)$ Thus, for romance novelists, but not other authors, a career

Table 7. Percent of authors exceeding key benchmarks.

\begin{tabular}{lccr}
\hline & 2009 & 2014 & \\
\hline $\begin{array}{l}\text { Female authors exceeding women's median income (bounds) } \\
\quad N=659^{\mathrm{a}}\end{array}$ & $22(19,25)$ & $31(2734)$ & $<0.001$ \\
$\begin{array}{l}\text { Authors exceeding } \$ 100,000 \text { (bounds) } \\
\quad n=668\end{array}$ & $9(7,12)$ & $17(14,20)$ & $<0.001$ \\
$\begin{array}{l}\text { Authors with no source of income other than romance writing (bounds) } \\
\quad n=660^{\mathrm{b}}\end{array}$ & $39(41,49)$ & $45(41,49)$ & $p<0.05$
\end{tabular}

\footnotetext{
${ }^{a}$ Because $98 \%$ of survey respondents were women, the U.S. women's median $(\$ 35,549$ in $2009 ; \$ 39,621$ in 2014$)$ provides a more accurate benchmark for this sample than the overall U.S. median. Therefore, respondents not self-identifying as women $(n=9)$ were excluded from this subsample (but included in all other analyses).

${ }^{b}$ Eight authors did not answer this question for both years and so are excluded.
} 
as a modestly paid, full-time writer seems to be more available now than before the digital disruption.

\section{Section III: Open-elite networks: Solidarity for the digital age?}

On all measures, romance writers appeared less precarious in 2014 than five years earlier. But why? It would be easy to dismiss such findings as merely the popular triumph of 'silly novels by lady novelists' (Eliot, 2010), driven by romance readers' ravenous appetites. ${ }^{1}$ But that would not explain why romance gained in market share over other genres after the digital disruption (Meyer \& McLean, 2016). Rather, my interviews with romance writers suggest that their gender-related status as literary outcasts in the 1970s and 1980s played a role in the creation of an unusual professional association - an 'open-elite' network that fostered the digital success of romance writers.

In the 1970s, romance exploded as a bestselling genre. Canadian publisher Harlequin's development of cheap mass-market paperbacks, sold in grocery and drug stores, boosted romance sales past other genres, including westerns and science-fiction (Davis, 1984; Radway, 1991). US publishers launched their own paperback romance lines in the late 1970s; the genre quickly became a cash cow for the industry.

Despite the financial success of romance, its writers received - and still receive - little respect (Krentz, 1992; Lois \& Gregson, 2015; Rodale, 2015). Major publications never reviewed romances; scholars dismissed romances as 'non-books' (Coser et al., 1982, p. 265), and other authors viewed romance writers with disdain.

'In the 1970s, we would go to writing conferences, and other writers would say, "You don't really belong here,"' said Rita Clay Estrada, a founder of Romance Writers of America (interview, 20 October 2015). In 1979, Estrada attended a meeting of a genre fiction coalition which met regularly with New York publishers. The coalition's authors represented mystery, thriller and science-fiction: Estrada asked the group to include romance writers. She was rebuffed: 'The guys weren't going to let us in. They said, "We're here to discuss things that you girls don't do."'

Estrada enlisted the support of romance editor Vivian Stephens, one of the few AfricanAmerican women in New York publishing at the time. They rallied dozens of other authors to launch Romance Writers of America (RWA) in 1980. RWA'S first conference, held that year in Houston, drew 680 authors from around the country.

This was an impressive turnout for a brand-new writers' organization, exceeding the roughly 500 authors who attended the Mystery Writers of America annual dinner during that era (Hubin, 1970). Even today, the Science Fiction and Fantasy Writers of America draws only 300-400 to their annual Nebula weekend conference and awards (Cat Rambo, SFFWA president, interview, 24 February 2016).

After that first conference, local RWA chapters quickly formed and organized regional events. Initially, these writers maintained ties through letters, phone calls and in-person meetings; over time, new digital information and communication technologies (ICTs) became the dominant means of contact. More than half of survey respondents reported networking with peers online 'at least once a month.'

From the start, RWA embraced a different model of professionalization than other writing associations. While only published authors could join other genre associations 
such as Mystery Writers of America (MWA) and Science Fiction and Fantasy Writers of America (SFFWA), RWA admitted anyone who wanted to 'seriously pursue a romance fiction writing career' and had completed a first draft (Allison Kelley, executive director, RWA, interview, 19 November 2015). This open membership policy differs markedly from traditional 'professionalization projects' (Sarfatti Larson, 1979), which seek to draw firm boundaries between amateur and professional, by monopolizing information and skills. Rather, RWA emphasized inclusion, mentoring and information sharing, largely because Estrada had disliked the lack of openness at the genre writers' meeting.

The guys ... didn't share when they stood up: they'd just say they signed a movie contract but not talk about how they did it. I wanted RWA to share information. When we find out information, we pass it on. (interview, 20 October 2015)

To this day, RWA embodies an unusually open information-sharing ethic, even among often-collegial writing associations. As Michael Capobianco, vice-president of the Sci-Fi Fantasy Writers Association, said:

I envy the romance writers sometimes. I wish we could focus more on exchanging contract information and sharing sales numbers much more than we do. It's like pulling teeth to get science fiction writers to share that. (interview, 18 December 2014)

In its emphasis on knowledge sharing, this romance writers' network presaged themes that later surfaced in fan fiction and peer-to-peer sharing models, where an ethic of collaboration, sharing work with strangers and the creation of a body of collective intelligence developed online (de Peuter, 2011). Henry Jenkins described this ethic as an outgrowth of the dispersed nature of new media - which contradicted tendencies of increasingly concentrated old media, and led to new types of 'voluntary, temporary and tactical' communities based on common pursuits and 'the mutual production and reciprocal exchange of knowledge' (Jenkins, 2004, p. 35). But for romance writers, this type of community ethic and collective intelligence rose long before digital media, creating an infrastructure that helped position them for rapid success with the rise of ICTS.

Many authors interviewed for this paper attributed the association's collaborative culture to gender. 'We're mostly women, and we're good at sharing,' said one author. This paper does not endorse claims of innate gender difference, but rather posits that the lived experiences of this mostly-female group contributed to its culture of open sharing and cooperation. Specifically, RWA's tightly knit network rose within a highly gendered power structure in traditional publishing, which devalued and stigmatized fiction written by women, about women and for women - even though many editors and literary agents were, themselves, women.

A culture of mentoring and collaboration manifests itself not only in RWA's open membership policy, but in its programmatic offerings and use of established members' cultural capital on behalf of new authors. RWA encourages knowledge transfer between elite, established authors and newcomers in multiple ways. In one striking example, the organization's leadership - mostly well-established authors - regularly leverage their social capital to introduce new authors to gatekeepers. They recruit prestigious editors to judge the annual Golden Heart awards for unpublished manuscripts, thereby bringing unpublished authors to the attention of elite editors. No other genre writing group has a national award for unpublished authors; for years, winning a Golden Heart was 
viewed as a virtual guarantee of landing a publisher. Such practices created multiple channels for knowledge exchange between elites and newcomers. RWA was also among the first writing conferences to institute author-editor appointments, where the RWA leadership - mostly established writers - would use their social capital to persuade editors to meet with attendees. Although such 'speed dating' events are now commonplace at writing conferences, RWA instituted their event in 1984, long before many other conferences even existed (Allison Kelly, personal communication, 20 March 2019).

\section{Open-elite networks and innovation}

With its emphasis on fostering new writers, the founders of RWA unintentionally created what network theorists call an 'open-elite network.' Such networks provide open channels of access between elites and newcomers. Padgett points to intertwined marriage and business networks in renaissance Florence as an open-elite system allowing for social mobility (Padgett, 2010); Powell and Owen-Smith argue that open-elite relations among biotech firms in the 1990s helped foster innovation and knowledge transfer after technological disruption (Powell \& Owen-Smith 2012). Members of such networks did not become 'ossified gatekeepers' because they formed 'multiple independent pathways' linking newcomers and elites (Padgett \& Powell, 2012, p. 271).

An important part of RWA's founding purpose was for experienced writers to teach the ropes to aspiring newcomers. Not surprisingly, then, RWA's annual conference featured published authors, speaking on panels and offering their guidance. Programs from RWA conferences show that as late as 2008, almost all conference speakers were published authors (Romance Writers of American, 2008, 2014).

In 2010, however, something surprising happened: the advice flow became two-way. That year, Apple and Amazon both announced that self-published authors would receive $70 \%$ of each sale (while traditionally published authors typically received 10-20\%). At first, well-established romance writers paid little attention. But unpublished writers were intrigued. Thanks to RWA's emphasis on mentoring and contests, many had complete, welledited manuscripts languishing on their hard drives. With nothing to lose, these authors self-published on Kindle or other platforms - some with astounding success.

'I'd been trying to get published for 20 years,' said Teresa Ragan of Sacramento (interview, 19 November 2014). In March 2011, she self-published six of her rejected manuscripts. A year later, she'd sold 300,000 books and signed a contract with an Amazon imprint. As of 2015, she had made more than $\$ 2$ million.

Because Ragan and other newcomers enjoyed open channels of communication with elite writers, news of their success quickly spread to traditional authors. 'I wasn't taking self-publishing seriously until I saw a friend at the conference. She grabbed my arm and said, 'I'm making money at self-publishing. Real money,' said one bestselling novelist (interview, 26 April 2016).

The open channels that had initially allowed newcomers to access elites now became two-way conduits. In 2013, RWA added a self-publishing track at its annual convention. By 2014, traditionally published authors no longer monopolized RWA conference panels; instead, about $10 \%$ of speakers were relative newcomers who had started out in self-publishing, compared with none in 2008 (Romance Writers of America, 2008, 2014). 
Today, the two-way information flow continues. 'teach new members about craft, and how to plot, and pacing. They teach me about technology, about advertising and promoting myself online. It's a give-and-take,' said Macmeans.

\section{Conclusion}

The data presented here show that, contrary to the assumptions of cultural industries scholars, romance writers became less precarious after a digital disruption. I argue that the unusually close and diverse network formed by romance writers, working in an intensely gendered industry, helped accelerated knowledge transfer in a way that later poised the group for success. This network combined in-person and ICT-facilitated networking to strengthen ties among writers and facilitate knowledge transfer in a period of accelerated innovation.

These data are necessarily limited: This is a voluntary, self-selected sample. Results do not represent non-RWA authors or less experienced RWA members. Future work more deeply probing differences between romance and other genres would add nuance to these results. Differences in respondent demographics between RWA and the Authors' Guild survey may explain some of the income differences. Most importantly, this paper presents only a snapshot of a disruption in progress; it is impossible to say if romance writers' upward trajectory will continue.

Nevertheless, this research offers the most in-depth survey to date of the professional practices and income of US fiction writers before and after the rise of digital publishing. ${ }^{2}$ This paper adds to feminist discussions of digital labor by connecting women's search for solidarity in the face of bias to specific work practices. It also contributes to cultural industries debates by proposing methods to quantify and explicate precarity, and by demonstrating that cultural workers are not necessarily worse off after digital disruptions. To the contrary, the research presented here suggests that specific social tactics, enhanced by ICTs, can increase workers' resilience, and create a more satisfying balance of creative and economic rewards, even under digital conditions. ${ }^{3}$

\section{Notes}

1. This paper adapts Hesmondhalgh's definition of cultural industries as those dealing with "production and circulation of texts" (Hesmondhalgh 2007, p. 12).

2. I generally employ "insecurity," but use "precarity" when referring to literature that specifically addresses the combination of unreliable pay, benefits, work assignments and pervasive insecurity rising from the risk regime.

3. Other author studies include the Survey of Authors' Income by the Authors Licensing and Collecting Agency in the UK ( $n=5500)$, and the forthcoming 2018 authors' income survey from the Authors' Guild of America $(n=5067)$. Also, the ongoing Authors' Earnings survey scrapes Amazon book rankings quarterly, and extrapolates income based on a reference table reported by self-selected authors. 


\section{Notes on contributor}

Christine Larson is Assistant Professor in the College of Media, Communication and Information and the Department of Journalism at the University of Colorado, Boulder. Her research explores the impact of digital technologies on underrepresented voices in media. [email: Christine.larson@colorado.edu]

\section{ORCID}

Christine Larson (D) http://orcid.org/0000-0002-4171-809X

\section{References}

The Authors Guild. (2015). The wages of writing 2015. The Authors Guild. Retrieved from https:// www.authorsguild.org/industry-advocacy/the-wages-of-writing/

Banks, M. (2007). The politics of cultural work. Basingstoke: Palgrave Macmillan.

Barley, S. R., \& Kunda, G. (2006). Gurus, hired guns, and warm bodies: Itinerant experts in a knowledge economy. Princeton, NJ: Princeton University Press.

Baym, N. K. (2018). Playing to the crowd: Musicians, audiences, and the intimate work of connec-

tion. New York, NY: New York University Press.

Beck, Ulrich. (2000). The brave new world of work. Maiden, MA: Polity.

Biernacki, P., \& Waldorf, D. (1981). Snowball wampling: Problems and techniques of chain referral

sampling. Sociological Methods \& Research, 10(2), 141-163.

Bridges, L. E. (2018). Flexible as freedom? The dynamics of creative industry work and the case

study of the editor in publishing. New Media \& Society, 20(4), 1303-1319.

Coker, M. (2015). Smashwords annual survey.

Coser, L. A., Kadushin, C., \& Powell, W. W. (1982). Books: The culture and commerce of publishing.

New York, NY: Basic Books.

Coser, L. A. (1979). Asymmetries in author-publisher relations. Society, 17(1), 34-37.

Davis, K. C. (1984). Two-bit culture: The paperbacking of America. Boston, MA: Houghton

Mifflin

Harcourt.

de Peuter, G. (2011). Creative economy and labor precarity: A contested convergence. Journal of Communication Inquiry, 35(4), 417-425.

Gill, R. (2006). Gender and the media (1st ed.). Malden, MA: Polity. 
Greco, A. N. (1997). The market for consumer books in the US: 1985-1995. Publishing Research Quarterly, 13(1), 3-40.

Hamilton, J. (2004). All the news that's fit to sell: How the market transforms information into news. Princeton, NJ: Princeton University Press.

Handy, C. (1991). The age of unreason. Boston, MA: Harvard Business Review Press.

Hesmondhalgh, D. (2007). The cultural industries. Los Angeles, CA: SAGE.

Hesmondhalgh, D., \& Baker, S. (2008). Creative work and emotional labour in the television industry. Theory, Culture \& Society, 25(7-8), 97-118.

Hesmondhalgh, D., \& Baker, S. (2011). Creative labour: media work in three cultural industries. London: Routledge.

Hildick-Smith, P. (2016, May 3). Personal communication providing unpublished analyses of Authors Guild data.

Holson, L. (2016, March 30). With romance novels booming, beefcake sells but it doesn't pay. New York Times.

Hubin, A. (1970, May 10). Criminals at large. The New York Times.

James-Enger, K. (2013). Six-figure freelancing: The writer's guide to making more money. Downers Grove, IL: Improvise Press.

Jenkins, H. (2004). The cultural logic of media convergence. International Journal of Cultural Studies, 7(1), 33-43.

Katz, Lawrence, \& Krueger, Alan. (2019). Understanding trends in alternative work arrangements. Working paper. National Bureau of Economic Research.

Krentz, J. A. (1992). Dangerous men and adventurous women: Romance writers on the appeal of the romance. Philadelphia, PA: University of Pennsylvania Press.

Larson, C. (2017). An economy of words: Precarity, solidarity and innovation in digital book publishing (Doctoral dissertation). Retrieved from https://searchworks.stanford.edu/view/12080408

Lobato, R., \& Thomas, J. (2015). The informal media economy. Cambridge: Polity.

Lois, J., \& Gregson, J. (2015). Sneers and leers: Romance writers and gendered sexual stigma. Gender \& Society, 29(4), 459-483.

Lowe, T. (2018). Perceived job and labor market insecurity in the United States: An assessment of workers' attitudes from 2004-2014. Work and Occupations, 45(3), 313-345.

Malin, B. J., \& Chandler, C. (2016). Free to work anxiously: Splintering precarity among drivers for Uber and Lyft. Communication, Culture \& Critique, 10(2017), 382-400.

McRobbie, A. (2013). In the culture society: Art, fashion and popular. Routledge.

McRobbie, A. (2015). Be creative: Making a living in the new culture industries. Malden, MA: Polity Press.

Meyer, K., \& McLean, K. (2016). The 2016 Nielsen Romance Market Snapshot. Nielsen Co.

Neff, G. (2012). Venture labor: work and the burden of risk in innovative industries. Cambridge, MA: MIT Press.

Neff, G., Wissinger, E., \& Zukin, S. (2005). Entrepreneurial labor among cultural producers: "Cool" jobs in "hot" industries. Social Semiotics, 15(3), 307-334.

Nieborg, D., \& Poell, T. (2018). The platformization of cultural production. Theorizing the contingent cultural commodity. New Media and Society. 20(11), 4275-4292.

Padgett, J. (2010). Open elite? Social mobility, marriage, and family in Florence, 1282-1494. Renaissance Quarterly, 63(2), 357-411.

Padgett, J., \& Powell, W. W. (2012). The emergence of organizations and markets. Princeton: Princeton University Press.

Perrin, A. (2018). Reading trends in America. Pew Research Center. Retrieved from https://www. pewresearch.org/fact-tank/2018/03/08/nearly-one-in-five-americans-now-listen-to-audiobooks/

Pink, D. (2002). Free agent nation: The future of working for yourself. New York, NY: Warner Books.

Powell, W. W., \& Owen-Smith, J. (2012). An open elite: Arbiters, catalysts, or gatekeepers in the dynamics of industry evolution. In The emergence of organizations and markets (pp. 466495). Princeton, NJ: Princeton University Press.

Powell, W. W. (1985). Getting into print: The decision-making process in scholarly publishing. Chicago, IL: University of Chicago Press. 
Radway, J. A. (1991). Reading the romance: Women, patriarchy, and popular literature. Chapel Hill: University of North Carolina Press.

Rodale, M. (2015). Dangerous books for girls: The bad reputation of romance novels explained. Seattle: Amazon Digital Services.

Romance Writers of America. (2017). Internal membership survey.

Romance Writers of America. (2008). Program from the annual conference. San Francisco, CA: Author.

Romance Writers of America. (2014). Program from the annual conference. San Antonio, TX: Author.

Rosen, S. (1981). The economics of superstars. The American Economic Review, 71(5), 845-858.

Ross, A. (2004). No-collar: the humane workplace and its hidden costs. Philadelphia, PA: Temple University Press.

Ross, A. (2009). Nice work if you can get it: Life and labor in precarious times. New York, NY: New York University Press.

Ryan, B. (1992). Making capital from culture: The corporate form of capitalist cultural production. New York, NY: Walter de Gruyter.

Sarfatti Larson, M. (1979). Professionalism: Rise and fall. International Journal of Health Services, 9 (4), 607-627.

Scolere, L., Pruchniewska, U., \& Duffy, B. E. (2018). Constructing the platform-specific self-brand: The labor of social media promotion. Social Media + Society, 4(3). doi:10.1177/ 2056305118784768

Stone, L., \& Stone, J. C. F. (1986). An open elite? England, 1540-1880. Oxford: Oxford University Press.

Striphas, T. (2009). The late age of print: Everyday book culture from consumerism to control. New York, NY: Columbia University Press.

Terranova, T. (2000). Free labor: Producing culture for the digital economy. Social Text, 18(2), 3358.

Terviö, M. (2009). Superstars and mediocrities: Market failure in the discovery of talent. Review of Economic Studies, 76(2), 829-850.

Thompson, J. B. (2012). Merchants of culture: The publishing business in the twenty-first century. New York, NY: Plume.

Thornton, P. H. (2004). Markets from culture: Institutional logics and organizational decisions in higher education publishing. Stanford, CA: Stanford Business Books.

Tremblay, M. A. (1955). The key informant technique. American Anthropologist, 59(4), 688-701.

Waldfogel, J., \& Reimers, I. (2015). Storming the gatekeepers: Digital disintermediation in the market for books. Information Economics and Policy, 31, 47-58.

Whiteside, T. (1981). The blockbuster complex: Conglomerates, show business, and book publishing. Middleton, CT: Wesleyan University Press. 